\title{
Two Serotypes of Sweetpotato feathery mottle virus in Uganda and Their Interaction with Resistant Sweetpotato Cultivars
}

\author{
Robert F. Karyeija, Jan F. Kreuze, Richard W. Gibson, and Jari P. T. Valkonen
}

\begin{abstract}
First author: Ministry of Agriculture, Animal Industry and Fisheries, c/o Kawanda Agricultural Research Institute, P.O. Box 7065, Kampala, Uganda, and Institute of Biotechnology, University of Helsinki, Finland, and Department of Plant Biology, Genetic Centre, Swedish University of Agricultural Sciences (SLU), Box 7080, S-750 07, Uppsala, Sweden; second and fourth authors: Department of Plant Biology, SLU, Uppsala, Sweden, and Institute of Biotechnology, University of Helsinki, Finland; and third author: Natural Resources Institute, University of Greenwich, Central Avenue, Chatham Maritime, Kent, ME4 4TB, U.K. Accepted for publication 4 August 2000.
\end{abstract}

\begin{abstract}
Karyeija, R. F., Kreuze, J. F., Gibson, R. W., and Valkonen, J. P. T. 2000. Two serotypes of Sweetpotato feathery mottle virus in Uganda and their interaction with resistant sweetpotato cultivars. Phytopathology 90: $1250-1255$.

Isolates of Sweetpotato feathery mottle virus (SPFMV, genus Potyvirus, family Potyviridae) were obtained in several districts of Uganda from sweetpotato plants infected with the sweetpotato virus disease (SPVD), the most important disease of this crop in Africa. A monoclonal antibody (MAb 7H8) raised against the coat proteins (CP) of a mixture of the SPFMV strain C (United States) and the isolate SPV-I (West Africa)

distinguished Ugandan SPFMV isolates into those detectable and not detectable by the MAb. These two serotypes differed in prevalence in different districts of Uganda and in two common sweetpotato cultivars. Both serotypes could be transmitted simultaneously by single aphids. The serotypes differed in their ability to systemically coinfect sweetpotatoes that were infected with Sweetpotato chlorotic stunt virus (SPCSV, genus Crinivirus), the virus required to induce SPVD in SPFMV-infected plants. One sweetpotato breeding line, resistant to SPFMV from the New World, was infected by graft-inoculation with all SPFMV isolates from Uganda. Another SPFMV-resistant sweetpotato line became infected with SPFMV and developed SPVD only following coinoculation with SPCSV.
\end{abstract}

The sweetpotato crop (Ipomoea batatas L., family Convolvulaceae) is the seventh most important food crop in the world and the fourth most important in the developing world (33). In subSaharan Africa, sweetpotato is mainly a subsistence and food security crop grown for family use by millions of people. Production is concentrated around Lake Victoria. Uganda has the secondlargest production in the world after China (33).

Sweetpotato feathery mottle virus (SPFMV; genus Potyvirus; family Potyviridae) (28) is the most common virus infecting sweetpotatoes in Africa $(16,17,27)$ and elsewhere in the world $(5,22)$. It is transmitted by aphids in a nonpersistent manner and, in East Africa, by aphid species that do not colonize sweetpotato $(3,4)$. In most East African sweetpotato cultivars, SPFMV causes no symptoms on the foliage (12). Virus titers are usually too low to be detected by standard enzyme-linked immunosorbent assay (ELISA) techniques and can be detected only by graft inoculation to susceptible indicator hosts, such as I. setosa Ker. Consequently, SPFMV infection alone has been considered to be of little importance to the yields of sweetpotato in East Africa.

However, sweetpotatoes infected with both SPFMV and an unrelated virus, Sweetpotato chlorotic stunt virus (SPCSV; genus Crinivirus; family Closteroviridae) (32), also known as Sweetpotato sunken vein virus (7) and Sweetpotato virus diseaseassociated closterovirus (31), show severe symptoms referred to as sweetpotato virus disease (SPVD) $(11,16,18)$. SPVD is the main disease of the crop (9), characterized by small, distorted leaves which are often narrow (strap-like) and crinkled, with a chlorotic mosaic or veinclearing and stunting of plants $(11,16,17)$.

Corresponding author: J. Valkonen; E-mail address: jari.valkonen@ vbiol.slu.se

Publication no. P-2000-0830-01R

(c) 2000 The American Phytopathological Society
SPVD-affected cultivars commonly produce less than half the tuberous root yield of symptomless ones $(11,13,16,23,25)$. SPCSV is transmitted by whiteflies (Bemisia tabaci Gennadius) that colonize sweetpotato (4). In contrast to SPFMV, SPCSV, when occurring alone in sweetpotato, has detectable titers in the fullgrown leaves, causes mild purpling or yellowing depending on the cultivar, and can cause some yield reduction (11). It is therefore remarkable that the symptoms of SPVD are more characteristic of those caused by potyviruses than criniviruses. The titers of only SPFMV are increased over 600-fold in the SPVD-affected plants and development of the severe symptoms of SPVD are correlated with the increase in titers of SPFMV (18). Hence, the severe symptoms of SPVD are probably mainly attributable to SPFMV.

Serological variability of SPFMV in Uganda has not been studied, although SPFMV isolates from East Africa are genetically different from SPFMV isolates from the rest of the world, including West Africa (20). Some variability has been detected within the coat protein (CP) gene sequences of the Ugandan isolates of SPFMV (20), suggesting that serological variability may also exist. The East African SPCSV represents a serotype different from the West African SPCSV and causes more severe symptoms $(1,11)$. Therefore, it was important to determine whether the Ugandan isolates of SPFMV were detected by a monoclonal antibody (MAb 7H8), raised to a mixture of the CPs of a West African SPFMV strain (SPV-I) and the 'common' strain C of SPFMV from the United States, that is known to recognize many but not all isolates of SPFMV (14).

The International Potato Center (CIP) has the mandate for working on sweetpotato in developing countries and has recognized that breeding for virus resistance is a priority for Africa (15). Some SPFMV-resistant sweetpotato clones, including 420020 and 420026, have been identified (8). They are known to be highly resistant and resistant, respectively, to infection with 
SPFMV in Peru (8). However, cultivars resistant to local virus strains in one area of the world may not necessarily be resistant to the strains present in another continent.

This study used MAb 7H8 to investigate serological variability among the Ugandan SPFMV isolates and to examine whether there are any links between serological and other biological properties. SPFMV isolates were collected from plants affected by SPVD in the field in Uganda during 3 years. They were tested for their ability to form SPVD in coinfection with a Ugandan isolate of SPCSV in the SPFMV-resistant sweetpotato clones. Two serotypes of SPFMV were identified and found to occur in different frequencies in the field; the explanation for this fact was sought. The data suggested that isolates of the two serotypes differ in their ability to systemically infect sweetpotato plants.

\section{MATERIALS AND METHODS}

Virus isolates. Sweetpotato plants of different cultivars affected by SPVD were sampled from farmers' fields in eight different districts in Uganda (Fig. 1). The sampling sites spanned a $500-\mathrm{km}$-wide region covering the main sweetpotato production areas of Uganda. Sampled SPVD-affected plants were initially grown in insect-proof screenhouses at Kawanda Agriculture Research Institute (KARI) or Namulonge Agriculture and Animal Research Institute (NAARI) (Fig. 1). Stem cuttings from selected plants were transferred to and planted in a greenhouse at the University of Helsinki, Finland, and grown under natural daylight extended to $16 \mathrm{~h}$ by illumination with sodium halide lamps. Daily minimum and maximum temperatures were 25 and $30^{\circ} \mathrm{C}$, respectively. Plants were watered with a solution containing $0.1 \%$ NPK (5-7-6) fertilizer (Kukkien Y-lannos; Kemira OY, Vaasa, Finland) twice a week.

Isolates of SPFMV were obtained from six SPVD-affected plants, each collected from a different Ugandan district (Table 1), using transmission by single aphids (Myzus persicae Sulz.) to $I$. setosa seedlings. Aphids that had been starved for $2 \mathrm{~h}$ were allowed $30 \mathrm{~s}$ to acquire the virus from SPVD-affected sweetpotato leaves and then transferred to I. setosa seedlings, one caged aphid per plant. The following morning, aphids were killed with an insecticide. SPFMV infection was detected by development of veinclearing symptoms, and confirmed by the nitrocellulose membrane ELISA (NCM-ELISA) (10) using polyclonal antibodies (PAb) to SPFMV (17) supplied by CIP (Lima, Peru) 10 days postinoculation. The "common" strain of SPFMV (SPFMV-C), originally isolated in North Carolina (6), was obtained in desiccated leaves from CIP and was mechanically inoculated to I. setosa.

SPCSV was isolated by mass transfer to an I. setosa seedling of whiteflies (Bemisia tabaci) collected from SPVD-affected plants of sweetpotato growing in the field at NAARI, Uganda $(1,12)$. Virus-free plants from cuttings of sweetpotato cv. Tanzania were graft inoculated using the SPCSV-infected I. setosa maintained in a greenhouse at the University of Helsinki, Finland.

Inoculation of resistant clones. Virus-free in vitro plantlets of sweetpotato clones 420020 and 420026 and cv. Tanzania were obtained from CIP. They were transferred to and maintained in pots of soil in the greenhouse at the University of Helsinki. In a first experiment, batches of seven virus-free plants of 420026, 420020 , and cv. Tanzania were graft inoculated. Within each batch of seven plants, four plants were graft inoculated with a scion from an aphid-inoculated I. setosa infected with only SPFMV and three were graft inoculated each with a scion from the original SPVD-affected sweetpotato clone. In a second experiment, two plants of the above-mentioned virus-free sweetpotato clones were grafted with a scion of I. setosa infected with only SPFMV, as above, and two plants were graft inoculated with a pair of scions, of which one was infected with SPFMV and the other with SPCSV. Inoculated sweetpotato plants were observed for symp- toms and tested for SPFMV by NCM-ELISA 18 and 46 days after grafting. Any plant testing negative for SPFMV was then grafted with scions obtained from virus-free I. setosa seedlings. Scions of I. setosa were observed for a further 28 days for possible symptom development and then tested for SPFMV by NCMELISA using the PAb. Both experiments were done twice.

Distribution of two SPFMV serotypes in Uganda. Leaf samples of sweetpotato with SPVD symptoms were collected from farmers' fields in four and five districts in July 1997 and January 1999, respectively (Fig. 1). Samples were tested by NCM-ELISA with SPFMV MAb 7H8, to distinguish the monoclonal reactive serotype, $\mathrm{MAb}(+)$, and the nonreactive serotype, $\mathrm{MAb}(-)$, of SPFMV.

Additional leaf samples were collected from two SPFMV-resistant cultivars, New Kawogo and Tanzania. Samples were obtained from SPVD-affected plants in the experimental fields of NAARI (Mpigi district) (Fig. 1) in September 1997 and April 1998 , and samples were again distinguished into $\mathrm{MAb}(+)$ and $\mathrm{MAb}(-)$ isolates using MAb 7H8 in NCM-ELISA. Sampling from symptomless plants was also done. A scion from each of the 100 sampled plants of New Kawogo and Tanzania was excised and grafted to a healthy I. setosa seedling and development of symptoms was monitored for 28 days. Plants that developed symptoms were tested by NCM-ELISA using the PAb and MAb 7H8.

Coinfection of two serotypes of SPFMV in SPVD-affected plants. Virus transmission with aphids was performed as described above, and the experiment was carried out twice. Aphids were introduced for access feeding to two SPVD-affected source plants (Mbl and Nam 6), both of which reacted with the MAb 7H8 but which, it was thought, might also be infected by MAb(-) isolates of SPFMV. Single aphids from each SPVD-affected source plant were then transferred to six plants at the 7- to 9-leaf stage per virus isolate (one aphid per plant) of $\mathrm{cv}$. Tanzania preinfected

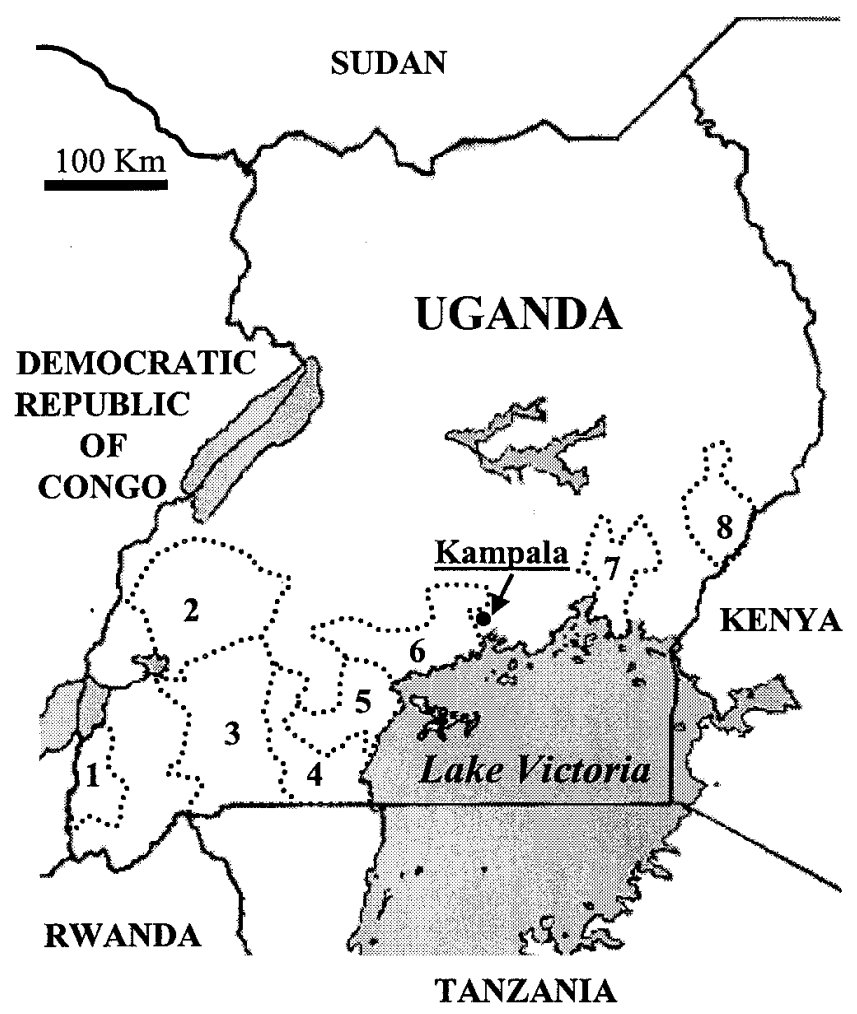

Fig. 1. Districts around Lake Victoria form the main sweetpotato production area in Uganda. The sampling sites in this study were: 1, Rukungiri; 2, Kabarole; 3, Mbarara; 4, Rakai; 5, Masaka; 6, Mpigi; 7, Iganga; and 8, Mbale. The Kawanda Agricultural Research Institute (KARI) and the Namulonge Agricultural and Animal Research Institute (NAARI) are located in the Mpigi district, approximately 10 and $20 \mathrm{~km}$, respectively, north from Kampala. 
with SPCSV. Aphids were caged on the leaves overnight and killed with an aphicide the following morning. The plants were observed for SPVD symptom expression and tested for SPFMV by triple-antibody sandwich (TAS)-ELISA and NCM-ELISA at 2-day intervals, starting from 15 days postinoculation. At 4 weeks postinoculation, SPFMV was immunocaptured, and the $\mathrm{CP}$ gene sequences were cloned by reverse transcription-polymerase chain reaction (RT-PCR) (19) and determined for isolates obtained from the plants that had been inoculated from the SPFMV-Mbl infected source plant. SPFMV was immunocaptured with MAb 7H8 from the plants that reacted with it in NCM-ELISA. However, the PAb used for immunocapturing SPFMV from the plants that showed SPVD symptoms, did not react with the MAb but reacted with the $\mathrm{PAb}$. The primers and the methods for cloning and sequencing of the SPFMV CP genes have been described (20).

Western analysis. Leaves $(0.3 \mathrm{~g})$ from the SPVD-affected sweetpotatoes or SPFMV-infected I. setosa were ground in $200 \mu \mathrm{l}$ of the homogenizing buffer $(0.25 \mathrm{M}$ Tris- $\mathrm{HCl}, 5 \mathrm{mM}$ EDTA, $0.1 \%$ ascorbic acid, and $1 \mathrm{mM}$ phenylmethylsulfonyl fluoride), a further $1.2 \mathrm{ml}$ of homogenizing buffer was added, and the sample was well mixed. The homogenate was left to stand for $10 \mathrm{~min}$ at room temperature, transferred to a new tube, and spun at $13,000 \mathrm{rpm}$ for $10 \mathrm{~min}$. The supernatant was transferred to a new tube and the amount of total protein was estimated by the Bradford method (measuring the absorbance at $\mathrm{A}_{595}$ using an ELISA reader, Benchmark Microplate Reader; BioRad, Hercules, CA). Separa-

TABLE 1. Sweetpotato feathery mottle virus (SPFMV) isolates used for inoculation in this study

\begin{tabular}{lllcc}
\hline & & & \multicolumn{2}{c}{ Reaction with $^{\mathrm{a}}$} \\
\cline { 3 - 5 } Isolate & \multicolumn{1}{c}{ Origin } & Reference & MAb 7H8 & PAb \\
\hline Kab 1 & Kabarole, Uganda & 20 & + & + \\
Mb1 & Mbale, Uganda & 20 & + & + \\
Nam 3 & Namulonge, Uganda & 20 & - & + \\
Nam 6 & Namulonge, Uganda & 20 & + & + \\
Mbr & Mbarara, Uganda & This study & - & + \\
Rak & Rakai, Uganda & 20 & - & + \\
Ruk & Rukungiri, Uganda & 20 & - & + \\
C & North Carolina, U.S. & 6 & - & + \\
\hline
\end{tabular}

${ }^{\mathrm{a}} \mathrm{MAb}=$ monoclonal antibody; $\mathrm{PAb}=$ polyclonal antibody. Ugandan isolates and isolate C of SPFMV from the United States were tested by nitrocellulose membrane-enzyme-linked immunosorbent assay using the monoclonal antibody MAb 7H8G2, originally described as MAb 7H8 (14), and the PAbs raised to the coat protein of SPFMV. Both were obtained via the International Potato Center (CIP).

TABLE 2. Prevalence of Sweetpotato feathery mottle virus (SPFMV) serotypes in Sweetpotato virus disease (SPVD)-affected plants sampled in five districts of Uganda

\begin{tabular}{lccc}
\hline & \multicolumn{2}{c}{ Total no. of } & \\
\cline { 2 - 3 } Sampling time, district & $\mathrm{PAb}(+)^{\mathrm{a}}$ & $\mathrm{MAb}(+)^{\mathrm{b}}$ & $\mathrm{MAb}(+)(\%)$ \\
\hline July 1997 & & & \\
Rukungiri & 64 & 6 & 9 \\
Masaka & 96 & 16 & 17 \\
Mpigi & 85 & 37 & 44 \\
Iganga & 30 & 2 & 9 \\
January 1999 & & & \\
Rukungiri & 102 & 12 & 12 \\
Rakai & 65 & 11 & 17 \\
Masaka & 68 & 9 & 13 \\
Mpigi & 74 & 18 & 18 \\
Iganga & 70 & 13 & 19 \\
\hline
\end{tabular}

a Number of samples from SPVD-affected plants that were clearly positive in nitrocellulose membrane-enzyme-linked immunosorbent assay (NCMELISA) for SPFMV using the polyclonal antibodies (PAb) to SPFMV coat protein.

b Number of the $\mathrm{PAb}(+)$ samples (plants) that tested positively with the monoclonal antibody (MAb 7H8) in NCM-ELISA. tion of the proteins was by sodium dodecyl sulfate-polyacrylamide gel electrophoresis (SDS-PAGE) (29) and electroblotting to NCM were carried out according to standard procedures (26). Membranes were developed using the PAb (dilution 1:1,000) or MAb $7 \mathrm{H} 8$ to SPFMV CP $(1: 1,000)$, both supplied by CIP, and antirabbit alkaline phosphatase (AP)-conjugated goat antibodies (SigmaAldrich, St. Louis) $(1: 15,000)$ or antimouse AP-conjugated rabbit antibodies (Sigma-Aldrich) $(1: 15,000)$, respectively, using the NCM-ELISA procedure. Signals were detected visually after $45 \mathrm{~min}$ $(\mathrm{PAb})$ or $2 \mathrm{~h}(\mathrm{MAb})$ of incubation of the membrane with the substrate (nitroblue tetrazolium [NBT] $0.1 \mathrm{mg} / \mathrm{ml}$ and 5-bromo-4chloro-3-indolyl phosphate [BCIP] $0.05 \mathrm{mg} / \mathrm{ml}$; Bio-Rad).

\section{RESULTS}

Serological detection of the Ugandan isolates of SPFMV. The Ugandan isolates of SPFMV could be divided into two groups based on detection, or failure to detect, with the MAb 7H8 (Table 1). Detection results with NCM-ELISA (Table 1) were consistent with results obtained using the TAS-ELISA (11) also used for testing some samples.

A strain of SPFMV causing root-crack symptoms in sweetpotatoes in North Carolina (SPFMV-RC) and West African SPFMV isolates can be detected with MAb 7H8 under denaturing conditions in Western blot analysis (14). Similarly, the SPFMV isolates from Uganda that were detected with the MAb 7H8 in ELISA were also detected by western blot analysis with the MAb 7H8 (data not shown), which suggests that the CP epitope recognized by MAb 7H8 is similar in both East and West African isolates of SPFMV, even though the overall $\mathrm{CP}$ sequences are different (20).

Detection of the two SPFMV serotypes in the field. A total of 108 SPVD-affected sweetpotato samples were collected from the field in Uganda in a preliminary survey. All 108 samples tested positive for SPFMV using PAb to SPFMV, which is consistent with the previous report that SPFMV is a component of SPVD in Uganda (11). Subsequently, surveys were done in four and five districts in 1997 and 1999 (Fig. 1), respectively, to assess whether or not any relative spatial or temporal changes in the prevalence of the two serotypes, distinguished by the MAb 7H8, occurred. In July 1997, there was a lot of rain; whereas, in January 1999, all sampled districts except Rukungiri were affected by drought. The samples from the dry districts in 1999 were tested first with PAb to exclude any plant in which the symptoms were those of drought rather than SPVD. A total of 654 plants affected by SPVD and infected with SPFMV were tested in the two years. At least 20 different cultivars were sampled, but many were impossible to identify reliably and, therefore, data could not be sorted based on cultivar. The $\mathrm{MAb}(+)$ isolates were much less common than the $\mathrm{MAb}(-)$ isolates in all districts except in the central district (Mpigi), where both serogroups were similarly common in 1997 (Table 2).

TABLE 3. Detection of Sweetpotato feathery mottle virus (SPFMV) isolates in the sweetpotato cvs. New Kawogo and Tanzania in the NAARI fields (Mpigi district) using the monoclonal antibody (MAb) 7H8

\begin{tabular}{|c|c|c|c|c|c|}
\hline \multirow[b]{2}{*}{ Sampling date } & \multicolumn{3}{|c|}{ Total no. of } & \multirow[b]{2}{*}{$\operatorname{MAb}(+)(\%)$} & \multirow[b]{2}{*}{$\chi^{2 \mathrm{c}}$} \\
\hline & Cultivar & Plants $^{\mathrm{a}}$ & $\overline{\mathrm{MAb}(+)^{\mathrm{b}}}$ & & \\
\hline \multirow[t]{2}{*}{ September 1997} & New & 144 & 57 & 39.6 & $31.6^{* * *}$ \\
\hline & Tanzania & 87 & 5 & 5.7 & \\
\hline April 1998 & New Kawogo & 61 & 26 & 42.6 & $70.8 * * *$ \\
\hline
\end{tabular}

${ }^{a}$ Number of samples from sweetpotato virus disease-affected plants that were clearly positive in nitrocellulose membrane-enzyme-linked immunosorbent assay (NCM-ELISA) for SPFMV using the polyclonal antibodies $(\mathrm{PAb})$ to SPFMV coat protein.

${ }^{b}$ Number of the $\mathrm{PAb}(+)$ samples (plants) that tested positively with MAb 7H8 in NCM-ELISA.

${ }^{c} \chi^{2}$ test for comparison between ratios of $\mathrm{MAb}(+)$ and $\mathrm{MAb}(-)$ isolates in cvs. New Kawogo and Tanzania; $* * *=$ differences are significant $(P<0.001)$. 
Cultivars Tanzania (known as SPN/0 in Tanzania, its country of origin) and New Kawogo are SPFMV-resistant landraces released in Uganda in 1995 (24). New Kawogo has become the predominant cultivar planted in the northern part of the Mpigi district (where KARI and NAARI are located; Fig. 1), largely due to its good field resistance to SPVD. A separate survey of SPFMV was therefore done in field trials of the two cultivars at NAARI in September 1997 and April 1998 in order to investigate whether the unusually high frequency of MAb(+) isolates in Mpigi district in 1997 could be associated with the predominance of New Kawogo there. Only a small proportion of $\mathrm{MAb}(+)$ isolates were detected in the SPVD-affected plants of Tanzania, similar to the

Experiment 1
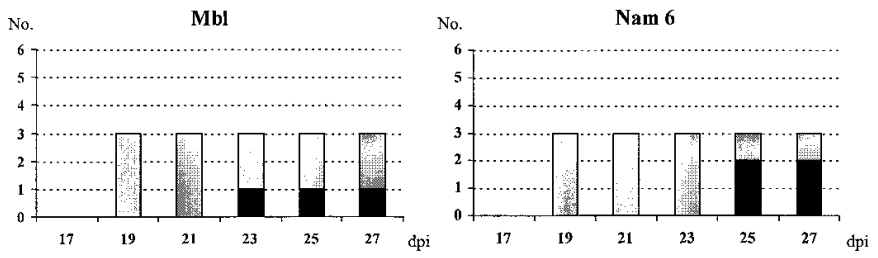

Experiment 2
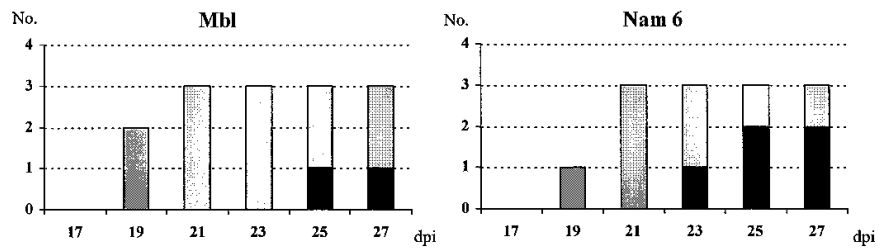

Plants reacting only with $\mathrm{PAb}$

Plants reacting with PAb and MAb

Fig. 2. Time of detection (days postinoculation, dpi) of two Sweetpotato feathery mottle virus (SPFMV) serotypes in the first leaf above the uppermost fully expanded leaf in plants of cv. Tanzania preinfected with Sweetpotato chlorotic stunt virus (SPCSV) and inoculated with single aphids previously allowed access to Mab(+), SPVD-affected plants (Mbl and Nam 6). Six and four plants were inoculated in experiments 1 and 2, respectively. The bars indicate the numbers (No.) of plants testing positive with the polyclonal antibodies (PAb) or the MAb 7H8 (MAb) that recognize both SPFMV serotypes or only the $\mathrm{MAb}(+)$ serotype, respectively. Data show that single aphids can transmit both serotypes simultaneously, but systemic infection with the $\mathrm{MAb}(+)$ serotype proceeds at a slower rate. situation in all districts sampled except Mpigi. However, for both sampling dates, the plants of New Kawogo affected by SPVD had a significantly $(P<0.001)$ greater proportion of $\mathrm{MAb}(+)$ isolates such that, as in sweetpotato generally in the Mpigi district, $\mathrm{MAb}(+)$ and $\mathrm{MAb}(-)$ isolates of SPFMV were in similar proportions (Table 3). Among the 100 asymptomatic plants of New Kawogo and Tanzania, only I. setosa seedlings grafted with a scion from five of the Tanzania plants developed the characteristic SPFMV symptoms consistent with most symptomless sweetpotato plants in Uganda being virus-free (12). These infected plants all tested positive in NCM-ELISA using the polyclonal antibodies to SPFMV but tested negative using the MAb 7H8.

The antibodies used could not differentiate whether or not a plant reacting with $\mathrm{MAb} 7 \mathrm{H} 8$ also contained a $\mathrm{MAb}(-)$ isolate; therefore, transmission of SPFMV was done from the SPVD-affected $\mathrm{MAb}(+)$ plants by single aphids to SPCSV-infected Tanzania (Fig. 2). Several inoculated plants developed SPVD and all tested positive with the PAb to SPFMV. However, initially, these affected plants all tested positive with only the polyclonal antibodies and, as shown in Figure 2, it was only later that some of the originally $\mathrm{MAb}(-)$ plants tested positive with $\mathrm{MAb} 7 \mathrm{H} 8$, showing that they were infected with both serotypes.

The SPFMV CP sequences were cloned by immunocapture (IC)-RT-PCR and determined from the plants of Tanzania inoculated by aphid transmission from the SPFMV-Mbl infected source plant (Fig. 2). The virus from the plants that tested $\mathrm{MAb}(+)$ in ELISA was obtained using MAb $7 \mathrm{H} 8$ for immunocapture, and the $\mathrm{CP}$ sequences were those of the isolate $\mathrm{Mbl}$ (20) as expected. In contrast, the $\mathrm{CP}$ sequence of a previously characterized $\mathrm{MAb}(-)$ isolate Nam 3 (20), but not Mbl, was detected in the SPVD-affected plants that tested $\mathrm{MAb}(-)$ and from which the virus was obtained using the PAb for immunocapture. These data confirmed that the SPFMV-Mbl infected source plant was coinfected with two isolates of SPFMV, which could not be resolved with the antibodies available. In conclusion, these data indicated that the original SPVD-affected source plants were infected with both $\mathrm{MAb}(+)$ and $\mathrm{MAb}(-)$ isolates, that single aphids could carry both serotypes simultaneously, and that the MAb(+) serotype spread systemically at a slower rate in coinfection with the MAb(-) serotype.

Ability to overcome resistance. The Ugandan SPFMV isolates representing the two serotypes were tested for their ability to overcome resistance reported to be effective against isolates of SPFMV from elsewhere. Two SPFMV-resistant sweetpotato clones, CIP 420020 and 420026 (8), were graft inoculated with isolates of Ugandan SPFMV and the isolate SPFMV-C from the

TABLE 4. Graft inoculation of sweetpotato clones 420020 and 420026 and cv. Tanzania with sweetpotato virus disease (SPVD)-affected sweetpotato scions or scions of Ipomoea setosa infected with isolates of Sweetpotato feathery mottle virus (SPFMV), each from a different district in Uganda

\begin{tabular}{|c|c|c|c|c|c|c|c|}
\hline \multirow[b]{3}{*}{ Isolate } & \multirow[b]{3}{*}{ Inoculum $^{\mathrm{a}}$} & \multicolumn{6}{|c|}{ Sweetpotato clone } \\
\hline & & \multicolumn{2}{|c|}{420026} & \multicolumn{2}{|c|}{420020} & \multicolumn{2}{|c|}{ Tanzania } \\
\hline & & Symptoms ${ }^{\mathrm{b}}$ & SPFMV $^{\mathrm{c}}$ & Symptoms & SPFMV test & Symptoms & SPFMV \\
\hline & SPFMV & CM & + & None & - & None & + \\
\hline Rak & SPVD & $\mathrm{VC}, \mathrm{S}, \mathrm{M}$ & + & $\mathrm{VC}, \mathrm{S}$ & + & $\mathrm{VC}, \mathrm{S}$ & + \\
\hline & SPFMV & $\mathrm{CM}$ & + & None & - & None & + \\
\hline Kab 1 & SPVD & VC,S,M & + & $\mathrm{VC}, \mathrm{S}$ & + & VC,S & + \\
\hline \multirow[t]{2}{*}{ Nam 3} & SPVD & $\mathrm{VC}, \mathrm{S}, \mathrm{M}$ & + & VC,S & + & VC,S & + \\
\hline & SPFMV & $\mathrm{CM}$ & + & None & - & None & + \\
\hline $\mathrm{Mbl}$ & SPFMV & $\mathrm{CM}$ & + & None & - & None & + \\
\hline C, U.S. ${ }^{\mathrm{d}}$ & SPFMV & None & - & None & - & None & + \\
\hline
\end{tabular}

${ }^{a}$ SPVD = scions from sweetpotato plants naturally infected with SPVD, or two scions of $I$. setosa, one infected with SPFMV and the other with SPCSV; SPFMV = scions from I. setosa to which SPFMV was transmitted from SPVD-affected sweetpotato by a single aphid.

${ }^{\mathrm{b}} \mathrm{VC}=$ vein clearing, $\mathrm{S}=$ stunting, $\mathrm{M}=$ mosaic, and $\mathrm{CM}=$ chlorotic mottle.

c SPFMV test comprised an initial nitrocellulose membrane-enzyme-linked immunosorbent assay test using polyclonal antibodies to SPFMV coat protein which, if negative, was followed by grafting with $I$. setosa $+=$ positive and $-=$ negative.

${ }^{\mathrm{d}}$ Strain C of SPFMV isolated in North Carolina, U.S. (6). 
United States. (Table 4). All Ugandan isolates induced a chlorotic mottle on leaves of the clone 420026, and these leaves tested positive for SPFMV in NCM-ELISA. In contrast, no Ugandan isolate induced any symptom in plants of clone 420020, the leaves tested negative for SPFMV in NCM-ELISA, and scions backgrafted to I. setosa seedlings did not induce symptoms. No infection with SPFMV-C was detected in either clone (Table 4). Plants of Tanzania graft inoculated with the isolates of SPFMV used in this study remained symptomless but, despite testing negative in NCM-ELISA, scions from plants inoculated with each of the SPFMV isolates all tested positive for SPFMV in back-grafting experiments with $I$. setosa seedlings. All plants (420020, 420026, and Tanzania) graft inoculated with both SPFMV and SPCSV either using scions of SPVD-affected sweetpotato or using a pair of scions of I. setosa (one of which was infected with SPFMV and the other with SPCSV) became stunted, developed small distorted leaves with chlorotic mosaic symptoms characteristic of SPVD, and tested positive for SPFMV by NCM-ELISA. The ability of the SPFMV isolates to overcome resistance in these sweetpotato clones was not correlated with reactivity with MAb 7H8.

\section{DISCUSSION}

The data of this study demonstrate that MAb 7H8 detects an epitope that is variable in Ugandan isolates of SPFMV. Surveys of the two SPFMV serotypes in different districts of Uganda in two years (1997 and 1999) showed that MAb(-) isolates were predominant, but $\mathrm{MAb}(+)$ isolates also were found in all districts in both years. Despite this, the MAb(+) isolates were more common in New Kawogo than in Tanzania grown in plots of the same fields and, although both isolates were transmissible even together by single aphids, the $\mathrm{MAb}(+)$ isolates consistently reached a detectable titer at a slower rate. Hence, the data suggested that cultivars grown in Uganda are less susceptible to $\mathrm{MAb}(+)$ isolates. The epitope identified by MAb 7H8 may be acting solely as a marker which, to now, appears to be distinguishing two SPFMV subpopulations that differ in their adaptation to sweetpotato. As such, it would be sequence differences in another portion of the viral genome that control this process. However, the possibility cannot be excluded that the epitope may itself be directly involved in this host adaptation, because amino acid changes at the $\mathrm{CP} N$ terminus can affect long-distance movement, virion accumulation, and aphid-transmissibility of potyviruses, some of these traits being affected by single amino acid changes $(2,21)$.

Resistance to SPFMV in the sweetpotato clone 420020 (8) was not overcome by Ugandan isolates irrespective of the serotype, indicating that its resistance is broader than that of 420026 . Clone 420020 expressed extreme resistance to SPFMV, no virus being detectable by ELISA or back-grafting with I. setosa. However, even its resistance was overcome in the presence of SPCSV and the plants developed typical symptoms of SPVD. It has been shown (18) that the titers of SPFMV isolate Kab 1 are enhanced over 600-fold in cv. Tanzania also infected with the isolate of SPCSV used in this study. Our results extend this earlier report, providing the additional evidence of extreme resistance to SPFMV being overcome by different Ugandan isolates of SPFMV in coinfection with SPCSV, although the two serotypes of SPFMV seemed to differ in their efficiency in inducing systemic infection. Consequently, selecting for resistance to SPFMV alone seems inappropriate, at least for Uganda, where most damage by SPFMV is done in complex with SPCSV, and plants must be selected for resistance to both viruses.

SPFMV is one of the most important potyviruses, although it has been relatively little studied until recently $(3,4,11,14,16-$ $18,20,22$ ). Sweetpotato (I. batatas) originated from the Americas, and its current pantropical distribution is largely the result of movement by humans. However, the genus Ipomoea is naturally pantropical (30). In another study (20), we have shown that, based on the CP gene sequences, SPFMV isolates from East Africa form a cluster separate from isolates from West Africa and the rest of the world, and our present findings show that both the $\mathrm{MAb}(+)$ and $\mathrm{MAb}(-)$ isolates from Uganda belong to this single cluster. Thus, our finding that Ugandan SPFMV isolates are able to infect the CIP clone 420026, in contrast to the isolate SPFMV-C and other isolates from the western hemisphere (8), seems consistent with the taxonomic distinctness of East African isolates and may reflect the fact that they are also biologically unique.

\section{ACKNOWLEDGMENTS}

We thank the Academy of Finland and FINNIDA, Finland (grant 34268), Sida/SAREC, Sweden (grant SWE-1997-141) (J. Valkonen) and the British Department for International Development (R. W. Gibson) for financial support; R. K. Kunywana and R. O. M. Mwanga (NAARI) for virus-free sweetpotato plants and SPVD-affected leaves of 'New Kawogo', respectively; O. A. Hidalgo (CIP) for virus-free in vitro sweetpotato plantlets; S. Fuentes (CIP) for the strain SPFMV-C, the polyclonal antisera, and the MAb 7H8G2; F. Rabenstein (BZK, Braunschweig, Germany) and B.-L. Lebbefors (Novartis Seeds AB, Sweden) for the colony of M. persicae; and S. Mäkelä (Dept. Applied Zoology, Helsinki), C. Högfeldt, B. Ekbom, and P. Persson (SLU, Uppsala) for help and space for aphid experiments. The DFID can accept no responsibility for any information provided or views expressed.

\section{LITERATURE CITED}

1. Alicai, T., Fenby, N. S., Gibson, R. W., Adipala, E., Vetten, H. J., Foster, G. D., and Seal S. E. 1999. Occurrence of two serotypes of sweet potato chlorotic stunt virus in East Africa and their associated differences in coat protein and HSP70 homologue gene sequences. Plant Pathol. 48:718-726.

2. Andrejeva, J., Puurand, Ü., Merits, A., Rabenstein, F., Järvekülg, L., and Valkonen, J. P. T. 1999. Potyvirus helper component-proteinase and coat protein $(\mathrm{CP})$ have coordinated functions in virus-host interactions and the same CP motif affects transmission and accumulation. J. Gen. Virol. 80:1133-1139.

3. Aritua, V., Adipala, E., Carey, E. E., and Gibson, R. W. 1998. The incidence of sweet potato virus disease and virus resistance of sweet potato grown in Uganda. Ann. Appl. Biol. 132:399-411.

4. Aritua, V., Alicai, T. Adipala, E., Carey, E. E., and Gibson, R. W. 1998. Aspects of resistance to sweet potato virus disease in sweet potato. Ann. Appl. Biol. 132:387-398.

5. Brunt, A. A., Crabtree, K., Dallwitz, M. J., Gibbs, A. J., and Watson, L. 1996. Viruses of Plants. Descriptions and Lists from the VIDE Database. CAB International, Wallingford, U.K.

6. Cali, B. B., and Moyer, J. W. 1981. Purification, serology, and particle morphology of two russet crack strains of sweet potato feathery mottle virus. Phytopathology 71:302-305.

7. Cohen, J., Frank, A., Vetten, H. J., Lesemann, D. E., and Loebestein, G. 1992. Purification and properties of closterovirus-like particles associated with a whitefly transmitted disease of sweet potato. Ann. Appl. Biol. 121:257-268.

8. Fuentes, S., and Salazar, L. F. 1996. Resistance to sweet potato feathery mottle virus. Pages 157-163 in: Characterization of Sweet Potato Viruses and Their Significance to Sweet Potato Production in Kenya. Final Report for the Period between January 1992 and December 1995. G. Loebenstein, ed. FRG-Israel Fund for Agricultural Research in Third World Countries, Israel.

9. Geddes, A. M. W. 1990. The relative importance of crop pests in subSaharan Africa. Natural Res. Inst. Bull. No. 36. N.R.I., Kent, U.K.

10. Gibb, K. S., and Padovan, A. C. 1993. Detection of sweet potato feathery mottle in sweet potato grown in Northern Australia using an efficient and simple assay. Intern. J. Pest Manage. 39:223-228.

11. Gibson, R. W., Mpembe, I., Alicai, T., Carey, E. E., Mwanga, R. O. M., Seal, S. E., and Vetten, H. J. 1998. Symptoms, etiology and serological analysis of sweet potato virus disease in Uganda. Plant Pathol. 47:95-102.

12. Gibson, R. W., Mwanga, R. O. M., Kasule S., Mpembe I., and Carey E. E. 1997. Apparent absence of viruses in most symptomless field-grown sweet potato in Uganda. Ann. Appl. Biol. 130:481-490.

13. Hahn, S. K. 1979. Effect of virus (SPVD) on growth and yield of sweet potato. Exp. Agric. 15:253-256.

14. Hammond, J., Jordan, R. L., Larsen, R. C., and Moyer, J. 1992. Use of polyclonal antisera and monoclonal antibodies to examine serological relationships among three filamentous viruses of sweet potato. Phytopathology 82:713-717.

15. International Potato Center 1991. Annual Report 1991. Lima, Peru. 
16. Karyeija, R. F., Gibson, R. W. and Valkonen, J. P. T. 1998. The significance of sweet-potato feathery mottle virus in subsistence sweet-potato production in Africa. Plant Dis. 82:4-15.

17. Karyeija, R. F., Gibson, R. W., and Valkonen, J. P. T. 1998. Resistance to sweet potato virus disease (SPVD) in wild East African Ipomoea spp. Ann. Appl. Biol. 133:39-44.

18. Karyeija, R. F., Kreuze, J. F., Gibson, R. W., and Valkonen, J. P. T. 2000. Synergistic interactions of a potyvirus and a phloem-limited crinivirus in sweet potato plants. Virology 269:26-36.

19. Koenig, R., Lüdecke, P., and Haeberlé, A. M. 1995. Detection of beet necrotic yellow vein virus strains, variants and mixed infections by examining single-strand conformation polymorphisms of immunocapture RT-PCR products. J. Gen. Virol. 76:2051-2055.

20. Kreuze, J. F., Karyeija, R. F., Gibson, R. W., and Valkonen, J. P. T. 2000. Comparisons of coat protein gene sequences show that East African isolates of Sweet potato feathery mottle virus form a genetically distinct group. Arch. Virol. 145:567-574.

21. López-Moya, J. J., and Pirone, T. P. 1998. Charge changes near the N terminus of the coat protein of two potyviruses affect virus movement. J. Gen. Virol. 79:161-165.

22. Moyer, J. W., and Salazar, L. F. 1989. Viruses and virus-like diseases of sweet potato. Plant Dis. 73:451-455.

23. Mukiibi, J. 1977. Effect of mosaic on the yield of sweet potatoes in Uganda. Pages 169-170 in: Proc. Tropical Root Crops. J. Cook, R. MacIntyre, and M. Graham, eds. CIAT, Cali, Colombia.

24. Mwanga, R. O. M., Odongo, B., Smit, N., Ocitti, pÓbwoya, C., Gibson, R. W. 1995. Submission to the variety release committee for release of sweet potato varieties. The Ugandan Ministry of Agriculture, Animal Industries and Fisheries, Application for inclusion of a crop/variety in the National Cultivar List No. F00009.

25. Ngeve, J. M., and Bouwkamp, J. C. 1991. Effect of sweet potato virus disease on the yield of sweet potato genotypes in Cameroon. Exp. Agric. 27:221-225.

26. Sambrook, J., Fritch, E. E., and Maniatis, T. 1989. Molecular cloning: A Laboratory Manual. 2nd ed. Cold Spring Harbor Laboratory, Cold Spring Harbor, NY.

27. Schaefers, G. A., and Terry, E. R. 1976. Insect transmission of sweet potato virus disease agents in Nigeria. Phytopathology 66:642-645.

28. Shukla, D. D., Ward, W. W., and Brunt, A. A. 1994. The Potyviridae. CAB International, Wallingford, UK.

29. Towbin, H., Staehelin, T., and Gordon, J. 1979. Electrophoretic transfer of proteins from polyacrylamide gels to nitrocellulose sheets: procedure and some applications. Proc. Natl. Acad. Sci. USA 76:4350-4354.

30. Verdcourt, B. 1963. Convolvulaceae. In: Flora of Tropical East Africa. C. E. Hubbard and E. Milne-Redhead, eds. Crown Agents for Overseas Governments and Administration, London.

31. Winter, S., Purac, A., Leggett, F., Frison, E. A., Rossel, H. W., and Hamilton, R. I. 1992. Partial characterization and molecular cloning of a Closterovirus from sweet potato infected with sweet potato virus disease complex from Nigeria. Phytopathology 82:896-875.

32. Wisler, G. C., Duffus, J. E., Liu, H.-Y., and Li, R. H. 1998. Ecology and epidemiology of whitefly-transmitted closteroviruses. Plant Dis. 82: 270-280.

33. World Bank 1996. World Development Report, 1995. Washington D.C. 